\title{
ETNOGRAFI KOMUNIKASI TRADISI SIRAMAN PADA PROSESI PERNIKAHAN ADAT SUNDA
}

\author{
Zikri Fachrul Nurhadi ${ }^{1}$, Ummu Salamah ${ }^{2}$, Tria Vidiyanti ${ }^{3}$ \\ 1,2,3 Konsentrasi Public Relations, Fakultas Ilmu Komunikasi, Universitas Garut \\ Jl. Raya Samarang No. 52A, Tarogong Kidul, Garut, Jawa Barat, 44151, Indonesia \\ No. Telp./HP: ${ }^{1} 085353325544,{ }^{2} 0816616730,{ }^{3} 081322601108$ \\ E-mail: ${ }^{1}$ zikri_fn@uniga.ac.id, ${ }^{2}$ ummusalamah31@gmail.com, ${ }^{3}$ triavidianti8@gmail.com
}

Naskah diterima tanggal 29 April 2018, direvisi tanggal 21 Mei 2018, disetujui tanggal 14 September 2018

\section{COMMUNICATION ETHNOGRAPHY ABOUT SIRAMAN TRADITION ON SUNDANESE WEDDING PROCESSION}

\begin{abstract}
This research is based on the tradition and culture in marriage in which is regarded as a ceremonial without knowing and understanding about the meaning and aims the Sundanese marriage ceremony. The purpose of this research is to find out and explain about communication component, communication situation, communication event, communication action. The purpose of communication in Siraman Tradition in Sundanese marriage ceremony. The method of this research is communication ethnography discussed of this research is language in communication behavior in difference approach and data collections technique is through participant observation, in dept interview, literature study and documentation. The informant of this research is 5 people and 2 people are as source among. Other siraman does, cultural observation and juru kawih through sampling purposive technique. The result of this research shows that in siraman tradition of sundanese marriage ceremony contains the verbal communications meaning in songs and nonverbal communication is in devices such are water, Candles, bokor, parfum, batik cloth, kebaya, gold and money. The pattern of communication in siraman tradition in sundanese marriage ceremony consist of order: communication pattern declarations communication pattern and requesi communications pattern.
\end{abstract}

Keyword: siraman tradition, marriage, sundanese culture, communication ethnography.

Abstrak. Penelitian ini dilatarbelakangi masalah tradisi dan kebudayaan dalam sebuah pernikahan yang dianggap hanya ceremonial tanpa mengetahui dan paham akan makna dari tujuan segala aktivitas yang terdapat pada ritual upacara pernikahan adat Sunda yang dilangsungkan. Tujuan penelitian ini untuk menemukan dan menjelaskan tentang komponen komunikasi, situasi komunikasi, peristiwa komunikasi, tindakan komunikasi, dan makna komunikasi tradisi siraman pada prosesi pernikahan adat Sunda. Metode penelitian ini adalah etnografi komunikasi yang mengkaji tentang peranan bahasa dalam perilaku komunikatif dalam suatu masyarakat yang berbeda-beda. Pendekatan penelitian ini menggunakan pendekatan kualitatif serta teknik pengumpulan data melalui observasi partisipan, wawancara mendalam, studi kepustakaan, dan dokumentasi. Informan pada penelitian ini berjumlah lima orang dan dua orang narasumber kunci di antaranya pelaku siraman, budayawan, dan juru kawih melalui teknik purposive sampling. Hasil penelitian menunjukkan bahwa dalam tradisi siraman pada prosesi pernikahan adat Sunda terdapat makna komunikasi verbal yang terdapat dalam lagu-lagu dan komunikasi nonverbal terdapat dalam alat dan bahan yang digunakan seperti air, lilin, bokor, parfum, kain batik, gayung, kebaya, emas, dan uang logam. Pola komunikasi tradisi siraman pada prosesi pernikahan adat Sunda terdiri atas: pola komunikasi perintah, pola komunikasi pernyataan, dan pola komunikasi permohonan.

Kata kunci: tradisi siraman, pernikahan, adat sunda, etnografi komunikasi. 


\section{PENDAHULUAN}

Pada dasarnya budaya merupakan cara hidup yang berkembang dan dimiliki bersama oleh sebuah kelompok orang dan diwariskan dari generasi ke generasi, menyatu dengan masyarakat dan hadir sebagai alat untuk berkomunikasi yang mendatangkan kepuasan dan perasaan-perasaan tertentu terhadap nilainilai budaya. Salah satu ciri kebudayaan Jawa Barat terdapat dalam suatu upacara pernikahan, upacara pernikahan ini diselenggarakan dalam rangka menyambut peristiwa pernikahan (Saripudin, 2010). Menurut Eliade (2002), pernikahan merupakan suatu peristiwa yang sangat sakral dan dinantikan setiap pasangan. Sakral yaitu memanifestasikan diri sebagai sebuah realitas yang secara keseluruhan berbeda tingkatannya dengan realitas-realitas "alami" (sakral sendiri bagi masyarakat Sunda yaitu sebagai sarana manusia berhubungan dengan ilahi) yang memiliki prinsip dasar masyarakat Sunda senantiasa dilandasi oleh tiga sifat utama, yakni silih asih, silih asuh, dan silih asah atau secara literal diartikan sebagai saling menyayangi, saling menjaga, dan mengajari. Ketiga sifat itu selalu tampak dalam berbagai upacara adat Sunda.

Landasan filosofis tradisi siraman pada prosesi pernikahan adat Sunda ini memiliki kelayakan untuk dijadikan kerangka sosialbudaya bagi orang Sunda kini dan mendatang. Filosofis tradisi siraman pada prosesi pernikahan adat Sunda ini memiliki keluwesan yang mampu menyerap pada kemajuan zaman dan mampu memberi situasi sosial baru yang nyaman bagi orang-orang yang melakukannya. Pandangan Kluckhohn (dalam Garna, 2009) yang menjelaskan bahwa konsep budaya tentang kebudayaan tradisi siraman pada prosesi pernikahan adat Sunda ini menghubungkan peringkat tingkah laku dengan kehidupan modern yang menarik, lebih menekankan pada simbolsimbol komunikasi yang penuh arti bagi kehidupan warga pendukung budayanya berfungsi sebagai komunikasi antarwarga dan cara hidup. Ada beberapa makna yang dapat diringkas dari pendapat Kluckhohn (Garna, 2009), yaitu, the total way of life of people, the social legacy, a precipitate of history learned behavior, a way of thinking, feeling and believing.

Dari penjelasan filosofis tentang tradisi siraman, maka pernikahan tentunya dipengaruhi oleh faktor kebudayaan atau tradisi di setiap daerahnya, salah satunya di Kabupaten Garut yang memiliki kekhasan atau ciri utama dengan melakukan beberapa aktivitas dalam rangkaian upacara pernikahan adat Sunda seperti nendeun omong yaitu pembicaraan orang tua atau utusan pihak lakilaki yang berniat mempersunting seorang gadis. Lamaran atau narosan yaitu tahap lanjut dari tahap pertama, proses ini dilakukan orang tua calon pengantin dan keluarga dekat, bedanya dari tahap pertama orang tua laki-laki biasanya mendatangi calon besannya dengan membawa bingkisan atau makanan (lamareun) sebagai simbol pengikat. Siraman yaitu memandikan calon pengantin agar bersih lahir dan batin, biasanya acara berlangsung siang hari menjelang sore hari di kediaman calon pengantin wanita. Bagi umat muslim acara ini terlebih dahulu diawali dengan pengajian. Rangkaian acara selanjutnya yaitu ngeyeuk seureuh, akad nikah, mapag panganten, sungkem, huap lingkung, nincak endog, sawer (Rosidi, Ekadjati \& Chaedar, 2006)

Salah satu tradisi dalam pernikahan adat Sunda di Kabupaten Garut yang peneliti pilih untuk diteliti adalah siraman. Tradisi siraman merupakan salah satu ritual yang menjadi bagian dari seluruh rangkaian upacara adat pernikahan dalam masyarakat Sunda. Seperti yang diungkapkan oleh salah satu informan berinisial AM (50) merupakan salah satu dari seniman kebudayaan Sunda di Kabupaten Garut dalam wawancaranya mengatakan "Siraman artinya memandikan, menyucikan diri secara lahir dan batin. Siraman dilakukan sehari sebelum ijab qobul dilakukan, siraman dimaksudkan agar calon pengantin siap dan mantap untuk menghadapi sebuah mahligai pernikahan dan berumah tangga, karena dalam siraman terdapat makna-makna tentang kehidupan" (Hasil Wawancara dengan Bapak Agus Mulyadi, pada tanggal 23 Juli 2017, bertempat di kediamannya). 
Siraman merupakan simbol penyucian diri dan simbol kesayangan orang tua terhadap anaknya, sebagaimana dulu "anaknya ketika kecil" dimandikan kedua orang tuanya. Rangkaian acara dalam prosesi siraman yaitu upacara pengajian, ngecagkeun aisan (melepaskan gendongan), ngaras (permohonan izin atau restu kepada kedua orang tua), sungkeman (meminta maaf sambil mencuci kaki kedua orang tua), siraman (menyiramkan air). Selain itu, perlengkapan yang digunakan dalam prosesi siraman adalah air, kembang tujuh rupa (kembang melati, kembang mawar, kembang kenanga, kembang sedap malam, kembang kantil, dan kembang melati gambir), tujuh lilin, tujuh helai selendang batik, satu helai handuk, baju (apok), bondu melati, bokor (tempat/wadah air), gayung, kendi, wewangian, dan souvenir siraman. Sebelum upacara siraman ini dilangsungkan, biasanya diselenggarakan pengajian. Sebelum pengajian dimulai, di tempat ini sudah disiapkan air setaman, yaitu air dari tujuh mata air/sumur yang ditaburi bunga tujuh rupa. Maksudnya, sebelum dimanfaatkan untuk memandikan kedua calon mempelai, air setaman itu lebih dulu didoakan ustaz/ustazah beserta orang-orang yang hadir di tempat itu. Pada siraman itu, kedua orang tua menyiramkan air "berbau tujuh macam kembang" kepada tubuh anaknya (Rezeki, 2015).

Siraman merupakan upacara yang lebih bersifat internal, seluruh keluarga besar berkumpul dan memberikan doa restu pada sang calon pengantin untuk memasuki fase baru kehidupan. Upacara siraman ini juga merupakan kesempatan bagi anak untuk memohon doa restu kepada orang tua maupun para sepuh. Tujuannya, agar dalam mengarungi hidup baru nanti ia mendapatkan restu dan limpahan kebaikan, itu sebabnya biasanya yang bertugas memandikan calon pengantin, selain kedua orang tuanya, juga para anggota keluarga atau orang-orang yang lebih tua dari calon pengantin. Siraman termasuk ke dalam komunikasi ritual, karena di dalam siraman ini ada ritual-ritual kecil yang dilakukan oleh calon pengantin pada saat prosesi berlangsung dalam rangkaian upacara pernikahan adat Sunda di Kabupaten Garut. Hal ini sependapat dengan Fiske
(2004), yaitu ritual-ritual kecil pada setiap peristiwa komunikasi terdapat gerakangerakan yang dilakukan oleh aktor yang ada dalam situasi komunikasi yang secara berurutan mempunyai makna, serta terdapat pula pada alat-alat dan bahan-bahan yang digunakan seperti pada tradisi siraman prosesi pernikahan adat Sunda.

Siraman ini mengandung maksud sebagai upaya meneruskan tradisi dan sekaligus merupakan langkah dan pelestarian nilai-nilai warisan budaya para leluhur yang terdahulu yang tersurat dan terkandung dalam upacara, dihayati, dan dikenal yang akhirnya dimiliki oleh generasi penerus. Penyajian upacara siraman adat Sunda yaitu dengan diiringi unsur-unsur musikal yang identik dengan kesenian Sunda yaitu kecapi suling yang membawakan tembang-tembang Sunda dan atau alunan musik etnis tembang Cianjuran (Budiman, 2008).

Pada saat prosesi siraman ini berlangsung diiringi oleh beberapa alunan lagu dan musik seperti Cacandran untuk pembukaan acara siraman, lagu Ayun Ambing pada saat prosesi calon pengantin dan kedua orang tua menuju tempat pelaminan, lagu Pangapungan pada saat ngaras, dan pada saat sungkem diiringi lagu Budak Ceurik. Sedangkan pada inti acara yaitu siraman menggunakan lagu Nimang, kemudian di akhir acara diakhiri dengan lalaguan kawih maupun tembang Sunda (Lerina, 2015). Setiap proses tahapan dalam prosesi pernikahan adat Sunda melibatkan perilaku yang disengaja dikarenakan pada setiap tahapan prosesnya sengaja mengirimkan sejumlah besar baik pesan verbal maupun pesan nonverbal dimana pesan tersebut memiliki makna bagi orang lain. Pesan-pesan tertentu dapat dikirim dengan cara yang berbeda oleh budaya yang berbeda pula. Seperti halnya dalam proses pernikahan adat Sunda memiliki makna yang terkandung disetiap proses tahapannya.

Penelitian ini menarik dilakukan dengan alasan dalam budaya atau tradisi pernikahan adat Sunda di Kabupaten Garut bukan hanya acara seremonial belaka namun memiliki makna secara verbal maupun nonverbal dalam setiap rangkaian acara dan simbolsimbol yang digunakannya serta generasi atau 
masyarakat Sunda sendiri sebagai pemilik warisan budaya, belum tentu mengetahui dan paham akan makna dan tujuan dari segala aktivitas yang terdapat pada ritual upacara pernikahan adat Sunda yang dilangsungkan. Alasan lainnya bahwa masyarakat Sunda khususnya yang ada di Kabupaten Garut tetap mengedepankan serta melestarikan tradisi dan budaya sebagai bagian rasa cinta dan peduli akan warisan budaya yang sudah lama merupakan identitas diri bagi orang Sunda. Hal ini juga sependapat dengan (Bahari, 2011), yang mengatakan bahwa orang Sunda tidak akan mudah terombang-ambing dalam menghadapi tantangan globalisasi yang mempunyai nilai-nilai baru dan asing, apabila dapat melestarikan nilai-nilai budaya yang sudah ada.

Sedangkan manfaat penelitian tradisi siraman pada pernikahan adat Sunda di era digital bahwasanya dengan berkembangnya zaman dan teknologi, memengaruhi pola pikir masyarakat sehingga terjadi pergeseran nilainilai budaya. Ini artinya eksistensi adat istiadat mengalami perkembangan dari bentuk aslinya. Di era digital khususnya budayabudaya Sunda akan lebih dirasakan oleh siapapun, karena budaya dan teknologi akan saling memengaruhi dan melengkapi. Teknologi dan kebudayaan memiliki peranan penting dalam kehidupan manusia. Teknologi juga merupakan salah satu komponen dari kebudayaan. Berdasarkan paparan yang telah dijelaskan, maka aksiologis penelitian ini memiliki nilai kebaruan dilihat dari segi pemaknaan terhadap simbol-simbol dalam siraman, dan dapat memberikan pengetahuan untuk memaknai siraman, sehingga krisis kesadaran masyarakat khususnya generasi muda terhadap pentingnya memahami pesan yang terkandung dalam tradisi siraman dapat terselesaikan. Memang tidaklah mudah bagi masyarakat untuk menjaga dan mempertahankan tradisi dan budaya warisan leluhur. Hal ini disebabkan oleh adanya anggapan bahwa tradisi leluhur sudah kuno. Faktor lain adalah keterbatasan orang-orang memahami dan mengetahui tentang apa dan bagaimana tradisi itu. Adapun pertanyaan dalam penelitian ini adalah bagaimana komponen komunikasi, situasi komunikasi, peristiwa komunikasi, tindakan komunikasi, dan makna komunikasi dalam tradisi siraman pada prosesi pernikahan adat Sunda. Berdasarkan uraian yang telah dipaparkan, maka peneliti mengambil judul penelitian tentang "Etnografi Komunikasi Tradisi Siraman pada Prosesi Pernikahan Adat Sunda".

\section{LANDASAN KONSEP}

\section{Penelitian Terdahulu}

Sejumlah penelitian tentang etnografi komunikasi tradisi siraman pada prosesi pernikahan adat Sunda khususnya di Kabupaten Garut belum banyak dilakukan. Hal ini, dimaksudkan untuk memberikan bahan perbandingan dan referensi agar tradisi siraman pada prosesi pernikahan adat Sunda dapat dipahami, sehingga penelitian ini mampu menyajikan hasil penelitian yang memiliki nilai originalitas. Peneliti mengacu pada penelitian yang pernah dilakukan sebelumnya untuk memperkaya kajian pustaka sehingga aspek-aspek penelitian terdahulu yang belum pernah diteliti dapat dilakukan dalam penelitian yang akan datang. Adapun penelitian-penelitian sebelumnya yang relevan dengan masalah yang diteliti dapat dilihat dalam Tabel 1.

Tabel 1

Perbedaan Penelitian dengan Penelitian Terdahulu

\begin{tabular}{lllllll}
\hline Penulis & Dewi & (2015). & Aktivitas & Fatmawati (2016). & Makna & Tria Vidiyanti, Zikri Fachrul \\
& Komunikasi Upacara Pernikahan & Pesan Tari Merak Dalam & Nurhadi, Ummu Salamah \\
& Suku Sasak (Studi Etnografi & Upacara Pernikahan Adat & \\
& Komunikasi Dalam Upacara & Sunda & (Analisis Semiotik \\
& Pernikahan Kawin Culik Di Desa & Roland & Barthes Tentang \\
& Rembitan, Lombok Tengah). & Makna Pesan Tari Merak
\end{tabular}


Dalam Upacara Pernikahan Adat Sunda Di Garut).

Deskripsi Penelitian

Fokus Penelitian

Tujuan Penelitian

Pendekatan

Kualitatif, Etnografi Komunikasi

Penelitian

Teknik

Pengumpulan

Data

Wawancara mendalam, observasi partisipan, studi pustaka, dan studi dokumentasi dari berbagai sumber.

ini Deskripsi penelitian ini Tengah.

Untuk mengetahui dan menjelaskan aktivitas komunikasi upacara pernikahan kawin culik yang dilaksanakan di Desa Rembitan, Lombok Tengah.

Perbedaan Perbedaan dengan penelitian ini dan adalah dari segi sasaran
Untuk mengetahui (1) makna denotasi pesan tari merak dalam upacara pernikahan adat Sunda (2) makna konotasi pesan tari merak dalam upacara pernikahan adat Sunda (3) makna mitos pesan tari merak dalam upacara pernikahan adat Sunda.

Kualitatif, teori analisis semiotik Roland Barthes

Wawancara mendalam dengan Narasumber, observasi, studi pustaka, dan studi dokumentasi. berfokus pada permasalahan pementasan Tari Merak dalam upacara pernikahan adat Sunda di Kabupaten Garut terdapat simbol-simbol atau tanda-tanda yang mempunyai makna denotasi, konotasi, dan mitos. Adapun makna pesan Tari Merak dalam upacara pernikahan adat Sunda dilihat dari sisi denotasi adalah atribut mahkota simbol kepala burung Merak, atribut sayap simbol sayap burung Merak, dan kostum yang bermotif bulu Merak merupakan simbol dalam Tari Merak. Makna konotasi yaitu tari merak yang dipentaskan dalam upacara pernikahan adat Sunda merupakan simbol tari persembahan untuk menyambut pengantin lakilaki. Makna mitos tari merak yaitu gerakan-gerakan yang ditampilkan itu merupakan simbol tarian yang menceritakan kehidupan burung Merak untuk menarik perhatian sang betina.

Fokus penelitian ini adalah bagaimana makna denotasi, konotasi, dan mitos pada tari merak dalam prosesi pernikahan adat Sunda.

Deskripsi penelitian ini bahwa dalam tradisi siraman pada prosesi pernikahan adat Sunda terdapat makna komunikasi verbal yang terdapat dalam lagu-lagu dan komunikasi nonverbal terdapat dalam alat dan bahan yang digunakan seperti air, lilin, bokor, parfum, kain batik, gayung, kebaya, emas, dan uang logam. Pola komunikasi tradisi siraman pada prosesi pernikahan adat Sunda terdiri atas: pola komunikasi perintah, pola komunikasi pernyataan, dan pola komunikasi permohonan

Fokus penelitian ini adalah bagaimana komponen komunikasi, situasi, peristiwa, tindakan, makna siraman pada prosesi pernikahan adat Sunda.

Untuk menemukan dan menjelaskan tentang model komunikasi tentang situasi komunikasi, peristiwa komunikasi, tindakan komunikasi, dan makna komunikasi dalam tradisi siraman pada prosesi pernikahan adat Sunda.

Kualitatif,

Komunikasi

Etnografi

Wawancara mendalam dengan para informan, observasi partisipatif, studi pustaka, dan studi dokumentasi.

Perbedaan dengan penelitian Perbedaan dengan penelitian ini adalah dari segi ini adalah dari segi 


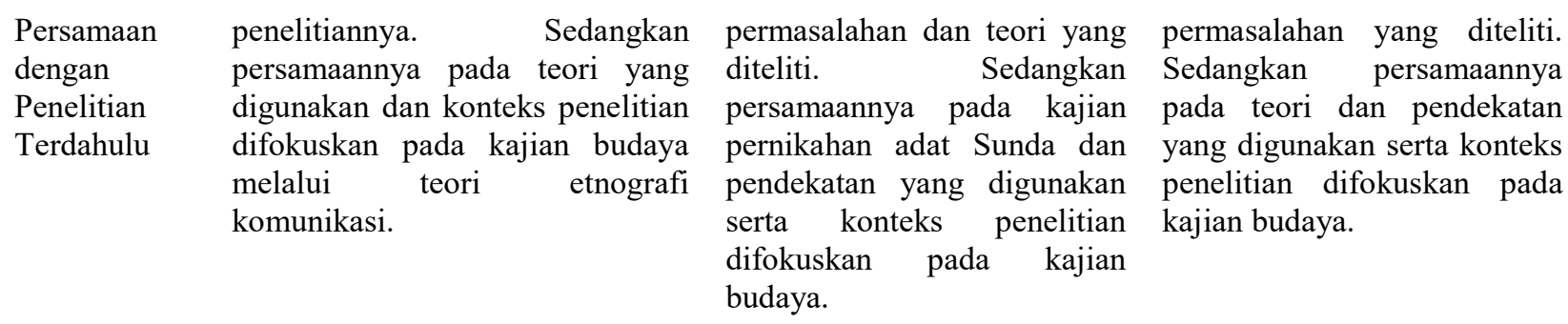

Sumber: diolah dari berbagai sumber.

\section{Teori Etnografi Komunikasi}

Etnografi komunikasi adalah salah satu dari sekian metode penelitian bidang komunikasi yang beranjak dari paradigma interpretative atau konstruktivis. Metode ini mengususkan diri pada kajian mengenai pola komunikasi yang digunakan oleh manusia dalam suatu masyarakat tutur.

Ruang lingkup kajian etnografi terdapat enam lingkup yaitu:

1. Pola dan fungsi komunikasi (patterns and functions of communications).

2. Hakikat dan definisi masyarakat tutur (nature and definition of speech community).

3. Cara-cara berkomunikasi (means of communicating).

4. Komponen-komponen kompetensi komunikasi (component of communicative competence).

5. Hubungan bahasa dengan pandangan dunia dan organisasi sosial (relationship of languange to world view and social organization).

6. Semesta dan ketidaksamaan linguistik dan sosial (linguistic and social universal and inqualities) (Hymes, 1974).

Ada beberapa istilah yang akan menjadi kekhasan dalam penelitian etnografi komunikasi, dan istilah ini nantinya akan menjadi objek penelitian etnografi komunikasi yaitu:

1. Masyarakat Tutur (speech community).

2. Aktivitas Komunikasi, unit diskrit komunikasi itu menurut Hymes (1974) yaitu: (a) Situasi komunikatif dan konteks terjadinya komunikasi; (b) Peristiwa komunikatif atau keseluruhan perangkat komponen yang utuh dimulai dengan tujuan umum komunikasi, topik umum yang sama, dan melibatkan partisipan yang secara umum menggunakan varietas bahasa yang sama, mempertahankan tone yang sama, dan kaidah-kaidah yang sama untuk interaksi, dalam setting yang sama; (c) Tindak komunikatif adalah fungsi interaksi tunggal seperti pernyataan, permohonan, perintah, ataupun perilaku nonverbal.

3. Komponen Komunikasi, yaitu (a) Genre atau tipe peristiwa komunikasi (misal lelucon, salam, perkenalan, dongeng, gosip, dan lain-lain); (b) Topik peristiwa komunikasi; (c) Tujuan dan fungsi peristiwa secara umum dan juga fungsi dan tujuan partisipan secara individual; (d) Setting termasuk lokasi, waktu, musim, dan aspek situasi lainnya; (e) Partisipan, termasuk usianya, jenis kelamin, etnik, status sosial, atau kategori lain yang relevan dan hubungannya satu sama lain; (f) Bentuk pesan, termasuk saluran verbal, nonverbal, dan hakikat kode yang digunakan, misalnya bahasa mana dan varietas mana; (g) Isi pesan, mencakup apa yang dikomunikasikan termasuk level konotatif dan referensi denotatif; (h) Urutan tindakan, atau urutan tindak komunikatif atau tindak tutur termasuk alih giliran atau fenomena pecakapan; (i) Kaidah interaksi; (j) Norma-norma interpretasi, termasuk pengetahuan umum, kebiasaan, kebudayaan, nilai dan norma yang dianut, tabu-tabu yang harus dihindari, dan sebagainya.

4. Kompetensi Komunikasi, terdiri dari: (a) Pengetahuan dan harapan tentang siapa yang bisa atau tidak bisa berbicara dalam setting tertentu? (b) Kapan mengatakannya? (c) Bilamana harus diam? (d) Siapa yang bisa diajak bicara? 
(e) Bagaimana berbicara kepada orangorang tertentu yang peran dan status sosialnya berbeda? (f) Apa perilaku nonverbal yang pantas? (g) Rutin yang bagaimana yang terjadi dalam alih giliran percakapan? (h) Bagaimana menawarkan bantuan? (i) Bagaimana cara meminta informasi dan sebagainya?

5. Varietas Bahasa, terdiri dari: (a) Partisipan dalam komunitas budaya lokal menciptakan makna. Mereka menggunakan kode-kode yang mempunyai pengertian yang sekiranya sama untuk mereka mengerti; (b) Komunikator dalam berbagai grup budaya harus dapat meng koordinasikan tindakan mereka. Harus ada beberapa sistem mengenai apa yang harus dilakukan dalam komunikasi; (c) Makna dan tindakan merupakan bagian dari individu. Dalam pengertian lain, mereka berbeda dari satu budaya terhadap budaya lain; (d) Tidak hanya pola-pola tindakan dan kode yang berbeda dari satu grup terhadap grup yang satu tetapi setiap grup juga mempunyai cara tersendiri untuk mengerti beberapa kode dan tindakan (Nurhadi, 2015).

\section{Tradisi Siraman pada Pernikahan Adat Sunda}

Ada hal-hal yang masih tetap dipertahankan pada upacara pernikahan adat Sunda di Jawa Barat, namun ada pula yang sudah mulai tidak digunakan atau dikurangi intensitasnya. Hal itu disebut Profan. Menurut Eliade (2002) profan berarti ruang dan waktu bersifat homogeni, tidak ada ruang istimewa, dan tidak ada waktu istimewa atau bisa dikatakan dengan pengingkaran terhadap adanya sesuatu yang sakral. Contohnya tahapan upacara melamar, atau nanyaan, nyawer, huap lingkung, seserahan, dan sebagainya. Kalaupun ada, sudah mengalami perubahan atau disesuaikan dengan kondisi tempat, kemampuan pemangku hajat, dan lingkungan zaman. Pada penelitian ini salah satunya tradisi siraman masih tetap dipertahankan eksistensinya. Tradisi siraman pada pernikahan adat Sunda mengandung pengertian yaitu memandikan calon pengantin perempuan dengan air yang telah dicampur dengan air bunga tujuh rupa (tujuh macam bunga wangi). Maksud dari upacara siraman adalah sebagai simbol bahwa untuk menuju sebuah mahligai rumah tangga yang suci harus pula diawali dengan tubuh serta niat yang suci pula. Upacara siraman atau ngebakan dimulai dengan ngecangkeun aisan, yang artinya ibu dari mempelai wanita melepaskan gendongan untuk menuju tempat siraman ditemani ayah yang setia mendampingi dengan membawa lilin. Hal itu mengandung makna bahwa kedua orang tua akan segera menyudahi tanggung jawabnya dan akan digantikan oleh suami putrinya. Lilin yang dibawakan sang ayah melambangkan tugasnya yang wajib memberi penerangan bagi putraputrinya. Setelah itu dilanjutkan dengan acara dipangkon, yakni calon mempelai wanita dipangku kedua orang tuanya. Berikutnya ngaras, mencuci kaki kedua orang tua yang diawali dengan membasuh kedua kaki sang ayah. Usai membasuh kaki kedua orang tua, disemprotkan juga minyak wangi yang mengungkapkan agar sampai kapan pun sang putri dapat membawa nama harum keluarga. Lalu calon mempelai wanita harus melewati tujuh lembar kain yang menyiratkan permohonan supaya kelak calon mempelai wanita senantiasa diberi kesabaran, kesehatan, ketawakalan, ketabahan, keteguhan iman yang kuat, dan selalu menjalankan agama. Puncaknya upacara siraman, calon mempelai wanita disirami air bunga yang masing-masing bunga memiliki artinya tersendiri. Bunga mawar agar calon pengantin selalu jujur, melati bermakna dapat membawa harum nama keluarga serta disukai oleh siapa saja, terakhir bunga kenanga yang diharap dapat membawa kesejukan dan keteduhan hati. Kemudian, sang ayah mengucurkan air wudhu kepada putrinya. Selesai siraman, mempelai wanita akan dibawa oleh perias untuk ngerik atau membersihkan bulu-bulu halus rambut di kamar pengantin. Terakhir, parebut bebetian \& hahampangan dimana diharapkan kedepannya kedua mempelai akan diberi kelancaran rezeki dan segera mendapatkan keturunan (Mustapa, 2010). 


\section{METODE PENELITIAN}

Penelitian ini menggunakan metode etnografi komunikasi, studi yang mengkaji peranan bahasa dalam perilaku komunikatif suatu masyarakat, yaitu cara-cara bagaimana bahasa digunakan dalam masyarakat yang berbeda-beda kebudayaannya (Ibrahim, 1992). Istilah etnografi komunikasi (ethnography of communication) merupakan pengembangan dari etnografi berbahasa (etnography of speaking). Sementara paradigma konstruktivis mengasumsikan bahwa manusia secara aktif menginterpretasikan pengalamannya dari sudut pandang orang yang mengalaminya atau dunia merupakan temuan-temuan yang diciptakan. Adapun alasan penelitian ini menggunakan etnografi komunikasi DellHymes, yaitu karena sebagai salah satu bagian dari sistem budaya, yang berfungsi di dalam keseluruhan konteks budaya, menghubungkan pola-pola bagian dari sistem budaya lainnya.

Tabel 2

Daftar Narasumber dan Informan

\begin{tabular}{clclc}
\hline No & \multicolumn{1}{c}{ Nama } & Usia & \multicolumn{1}{c}{ Pekerjaan } & Status \\
\hline 1 & Agus Mulyadi & 50 Tahun & Pemandu upacara adat pernikahan Sunda & Narasumber \\
2 & Anting Irawan & 58 Tahun & Pemandu upacara adat pernikahan Sunda & Narasumber \\
3 & Endah Nurfitriana & 27 Tahun & Pelaku siraman & Informan \\
4 & Aprilia Damayanti & 25 Tahun & Pelaku siraman & Informan \\
5 & Seny & 39 Tahun & Pelaku siraman & Informan \\
6 & Erni Nurbaeti & 48 Tahun & Juru kawih & Informan \\
7 & Utju Jubaedah & 50 Tahun & PNS & Informan
\end{tabular}

Sumber: Hasil Wawancara, 2017

Subjek pada penelitian ini adalah lima orang informan dan dua narasumber merupakan seniman dan budayawan Sunda di Kota Garut. Informan merupakan pasangan yang sudah menikah dan melaksanakan prosesi siraman dalam rangkaian upacara pernikahan adat Sunda di Kota Garut, berdomisili di Garut, asli orang Sunda. Teknik penentuan informan ini dengan teknik purposive sampling. Pemilihan informan didasarkan kepada informan yang mampu menggambarkan kembali fenomena yang telah dialaminya serta bersedia untuk diwawancara dan direkam aktivitasnya selama wawancara atau selama penelitian berlangsung. Teknik pengumpulan data yang digunakan adalah observasi partisipan, wawancara mendalam, dokumentasi, dan studi kepustakaan. Berikut penjelasan informan dan narasumber pada Tabel 2 .

\section{HASIL PENELITIAN DAN PEMBAHASAN}

\section{Komponen Komunikasi dalam Tradisi Siraman pada Prosesi Pernikahan Adat Sunda}

Berdasarkan hasil penelitian tentang tradisi siraman pada prosesi pernikahan adat Sunda yang telah dilakukan oleh peneliti di lapangan baik dengan wawancara langsung kepada informan dan narasumber maupun observasi partisipan, dapat dijelaskan dari beberapa informan di antaranya terdiri dari penata rias, juru kawih, dan orang yang sudah menikah dengan melaksanakan siraman atau pelaku siraman. Pada wawancara ini peneliti memberikan pertanyaan seputar pemahaman tentang siraman, seperti yang dijelaskan Endah Nurfitriana, yaitu:

"Siraman teh suatu proses adat istiadat dari budaya Sunda, tujuanna kangge minta ijin dan doa restu ke orangtua, perlengkapan $n u$ dianggo mah 
kembang nu dibonduken kembang malati, acuk putih, samping kebat, upami anu dianggo pengajian sungkem eta mh kembang anu tujuh rupi sajabi kembang mawar naon deui nya nu koneng teh nya da nu nyiapkeunna raka pokokna mah kembang nu 7 rupi weh. Teras lilin, artos logam eta teh persyaratan teras disawerken artosna mah. teras ngangge emas eta mah dilebetkeun heula kanu kendi teras dianggekeun emas na mah, nya cai na mah ke dibuang sambil disawerkeun, eta mah simbolis artina mah kangge pamageuh meh lancar saurna mah. Pas sungkeman nu diangge na parfum, teras nyere nu dipotongkeun teras dialungken pas ngke siraman, pelaksanaannya satu hari sebelum hari pernikahan, yang hadir Ibu-ibu pengajian, sodara mah kedah sadayana tujuhanna nyaeta raka-raka eta kan nu utamina mah, tatanggi, kerabat terdekat, bahasa na mah kan sok ngangge bahasa sunda ledok ah tapi ngartos, tidak sulit dimengerti". (Hasil wawancara dengan Ibu Endah Nurfitriana pada hari Jum'at, 21 Juli 2017 pukul 10.00 di Cipanas Tarogong, Garut).

Berdasarkan paparan yang telah dijelaskan dari salah satu informan, maka komponen-komponen komunikasi yang berperan dalam membentuk suatu peristiwa komunikasi dalam tradisi siraman pada prosesi pernikahan adat Sunda disajikan di Tabel 3.

\section{Tabel 3}

\section{Komponen Komunikasi Tradisi Siraman pada Prosesi Pernikahan Adat Sunda}

\begin{tabular}{ll}
\hline $\begin{array}{l}\text { Komponen } \\
\text { Komunikasi }\end{array}$ & Penjelasan Komponen Komunikasi \\
\hline $\begin{array}{l}\text { Genre atau tipe } \\
\text { peristiwa }\end{array}$ & $\begin{array}{l}\text { Dalam penelitian tradisi siraman pada prosesi pernikahan adat Sunda, genre-nya adalah doa } \\
\text { adat pernikahan. Doa adat ini memiliki makna hal-hal yang baik dalam setiap kehidupan } \\
\text { komunikasi }\end{array}$ \\
terutama doa terbaik menjalankan sebuah rumah tangga.
\end{tabular}

Topik Peristiwa

Komunikasi

Tujuan

Setting atau Latar Setting atau latar adalah komponen bahasa yang mengacu kepada ruang dan waktu, serta kapan komunikasi tradisi digunakan.

Partisipan

Bentuk Pesan

Isi Pesan

Urutan Tindakan

Topik atau fokus referensi komunikasi dalam tradisi siraman pada prosesi pernikahan adat Sunda adalah memohon restu duniawi dan restu surgawi dari kedua orang tua khususnya dan umumnya dari para kerabat untuk meminta izin menikah serta meminta doa kepada Allah SWT.

Tujuan dari komunikasi dalam tradisi siraman yang dijalankan masyarakat Sunda adalah untuk mendapatkan restu duniawi dan restu surgawi dari kedua orang tua khususnya dan umumnya dari para kerabat untuk meminta izin.

Partisipan dalam komunikasi tradisi siraman pada prosesi pernikahan adat Sunda yang dijalankan masyarakat adat Sunda di Kabupaten Garut terdiri atas kedua orang tua calon pengantin, kakak-kakak, adik-adik, paman, bibi, uwa-uwa, kerabat terdekat, tetangga, dan orang-orang yang dituakan atau para sepuh.

Bentuk pesan dalam komunikasi tradisi siraman pada prosesi pernikahan adat Sunda adalah pesan verbal yang diucapkan dalam bentuk doa, prolog, dan lagu-lagu. Selain pesan verbal juga digunakan pesan-pesan nonverbal berupa alat-alat dan bahan sebagai pesan simbolik dalam tradisi siraman. Bahasa yang digunakan dalam komunikasi tradisi siraman pada prosesi pernikahan adat Sunda adalah bahasa Sunda puitis menyerupai syair pantun yang terdapat dalam lagu dan bahasa Sunda halus.

Isi pesan komunikasi tradisi siraman pada prosesi pernikahan adat Sunda berhubungan dengan karakteristik berbahasa yang ada pada tradisi pernikahan yang mereka jalani. Komunikasi dalam tradisi yang diucapkan melalui doa berisikan permohonan dan harapan kepada kepada Tuhan sebagai wujud kekuatan tertinggi yang mereka percaya dan yakini. Sedangkan komunikasi dalam bentuk nonverbal lebih kepada pemaknaan atas simbol-simbol yang sarat dengan makna-makna.

Komunikasi dalam tradisi siraman pada prosesi pernikahan adat Sunda adalah tetap, yakni dalam setiap komunikasinya tetap dalam bentuk adat budaya Sunda, selalu diawali dengan sapaan dan dikuti dengan permohonan dan harapan kepada Tuhan sebagai wujud kekuatan tertinggi yang mereka percaya dan yakini. Urutan peristiwa dalam tradisi siraman pada prosesi pernikahan adat Sunda berbeda, hal ini berhubungan dengan tradisi yang berbeda situasi. Situasi komunikasi tradisi pada tradisi siraman adat Sunda ini dijalankan berdasarkan ketetapan rangkaian acara yakni mulai dari pengajian, ngecagkeun aisan, ngaras, dan sungkeman kemudian siraman. 
Kaidah Interaksi Komunikasi dalam tradisi siraman pada prosesi pernikahan adat Sunda sangat memperhatikan hal-hal penting yang wajib, yakni partisipasi menyeluruh dari keluarga, kerabat dekat, tetangga, dan berbagai peralatan untuk menunjang terlaksananya tradisi siraman pada prosesi pernikahan adat Sunda ini.

Norma Komunikasi dalam tradisi siraman yang dijalankan membuahkan penghayatan nilai-nilai Interpretasi keteraturan pada masyarakat.

Sumber: Hasil Wawancara dan Pengamatan Peneliti, 2017

\section{Setting Komunikasi}

Setting komunikasi dalam tradisi siraman pada prosesi pernikahan adat Sunda, yaitu:

1. Pengajian.

a. Apa yang dilakukan. Pengajian adalah tahapan pertama dalam rangkaian tradisi siraman. Pengajian merupakan kegiatan membaca ayat suci Al-Quran yang dilaksanakan oleh ibu-ibu pengajian yang berada di lingkungan sekitar acara tradisi siraman diadakan. Biasanya diawali oleh seorang ustaz/ustazah.

b. Mengapa dilakukan. Pengajian dilakukan untuk berdoa memohon keselamatan dan keberkahan bagi calon pengantin dan bagi semua yang hadir.

c. Pemimpin acara. Pengajian biasanya diawali oleh seorang ustaz/ustazah sebagai pembuka acara dalam pengajian.

d. Tempat pelaksanaan. Pengajian biasanya dilaksanakan di dalam rumah calon pengantin yaitu di bagian rumah yang memiliki ruangan yang cukup luas.

2. Ngecagkeun Aisan

a. Apa yang dilakukan. Ngecagkeun aisan adalah rangkaian acara kedua yaitu rangkaian acara yang dimulai dengan calon pengantin keluar dari kamar dengan didampingi kedua orang tua, kemudian sang ayah dan ibu melilitkan kain batik (kain samping) secara simbolis kepada putrinya menuju ruang tengah sampai ke tempat/kursi orang tua untuk selanjutnya sungkeman.

b. Mengapa dilakukan. Ngecagkeun aisan dilakukan sebagai tradisi budaya Sunda yang bermakna orang tua melepaskan tanggung jawab terhadap anaknya karena dengan memutuskan untuk menikah maka sang anak menjadi tanggung jawab suaminya.
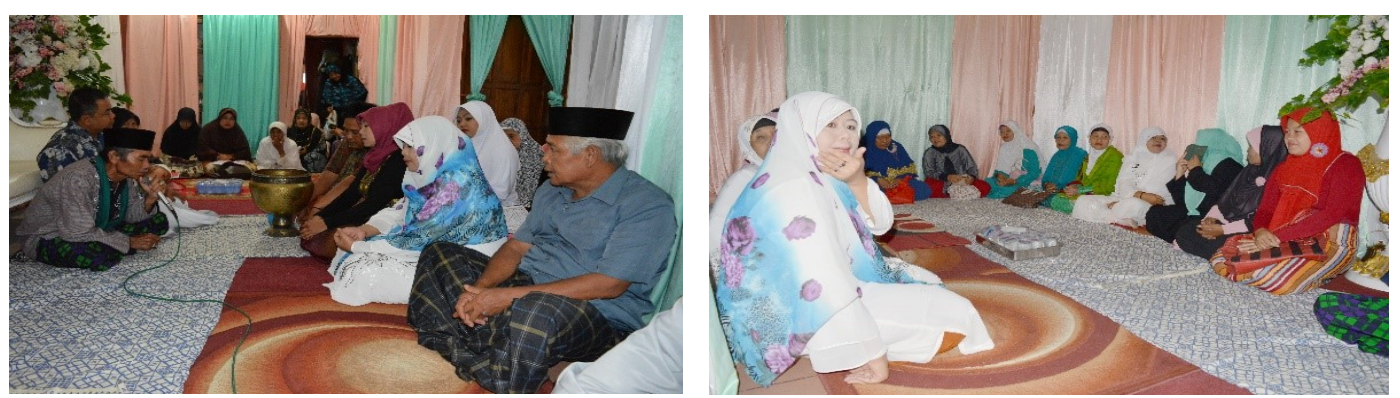

Gambar 1. Pengajian
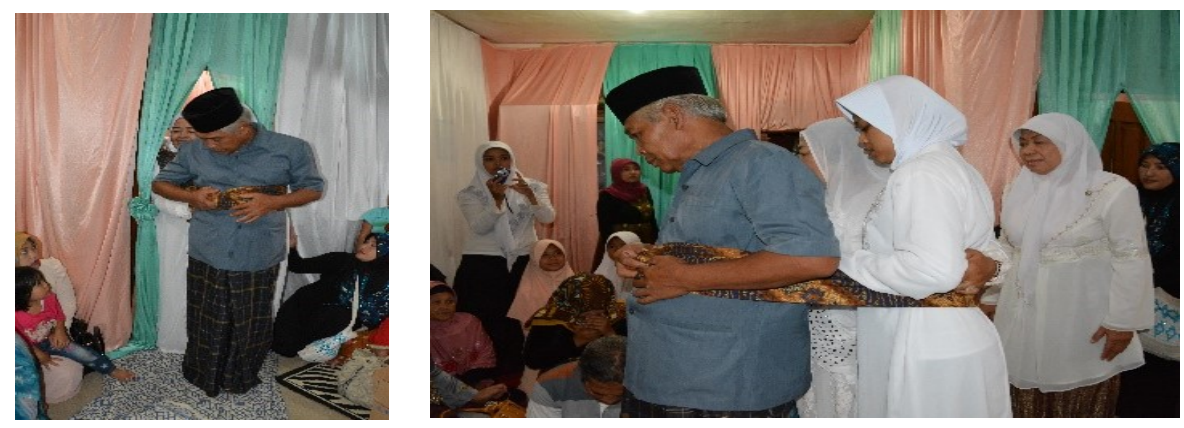

Gambar 2. Ngecagkeun Aisan 
c. Pemimpin acara. Pemimpin jalannya acara ini adalah juru tembang dan $\mathrm{MC}$, biasanya ngecagkeun aisan sambil diiringi alunan musik dan lagu Nimang serta ditambahkan prolog oleh MC.

d. Tempat pelaksanaan. Dimulai dari dalam kamar calon pengantin kemudian berjalan menuju dua kursi yang telah disiapkan untuk kedua orang tua di ruang tengah rumah.

3. Ngaras dan Sungkeman.

a. Apa yang dilakukan. Ngaras dan sungkeman adalah rangkaian acara ketiga yaitu rangkaian acara yang dimulai dari kedua orang tua duduk di kursi yang telah dipersiapkan sebelumnya, kemudian sang anak duduk di bawah menghadap ke kedua orang tua. Tujuannya adalah untuk meminta maaf dan meminta doa restu demi kelancaran pernikahan esok hari dan demi kelanggengan pernikahan. Kemudian lilin yang menyala ditiup oleh calon pengantin sesuai arahan penata acara. Lalu sang anak mencuci kaki ibu terlebih dahulu, mengelap kaki dengan handuk kecil, kemudian menyemprotkan parfum. Setelah itu sang anak mencium kaki ibu dan dibantu oleh MC sebagai prolog.

4. Siraman.

a. Apa yang dilakukan. Acara diawali calon pengantin didampingi oleh ayah dan ibunya menuju tempat siraman yang sudah dipersiapkan dengan diiringi alunan musik instrumen Ayun Ambing dan dibantu prolog oleh MC. Pertama, calon pengantin berwudhu dari air kendi yang di kucurkan oleh ayahnya. Kemudian menyiramkan air pertama kali dilakukan oleh ayah dan ibu nya secara bergiliran sebanyak tiga kali, kemudian dilanjutkan oleh nenek, kakek, kakak, adik, kerabat, tetangga. Jumlah orang yang menyiramkan tidak dibatasi tetapi harus melihat situasi dan kondisi calon pengantin supaya tubuh calon pengantin tidak kedinginan. Air tersebut disimpan dalam bokor yang terbuat dari kuningan.

b. Mengapa dilakukan. Siraman dilakukan dengan tujuan membersihkan diri calon pengantin secara lahir dan batin supaya calon pengantin dalam keadaan diri dan hati yang bersih supaya siap menghadapi rumah tangga.

c. Pemimpin acara. Pemimpin acara dilakukan oleh juru tembang dan $\mathrm{MC}$ sebagai prolog.

d. Tempat pelaksanaan. Tempat pelaksanaan yaitu di halaman rumah atau teras rumah yang sudah dihiasi dengan ornamen adat Sunda.
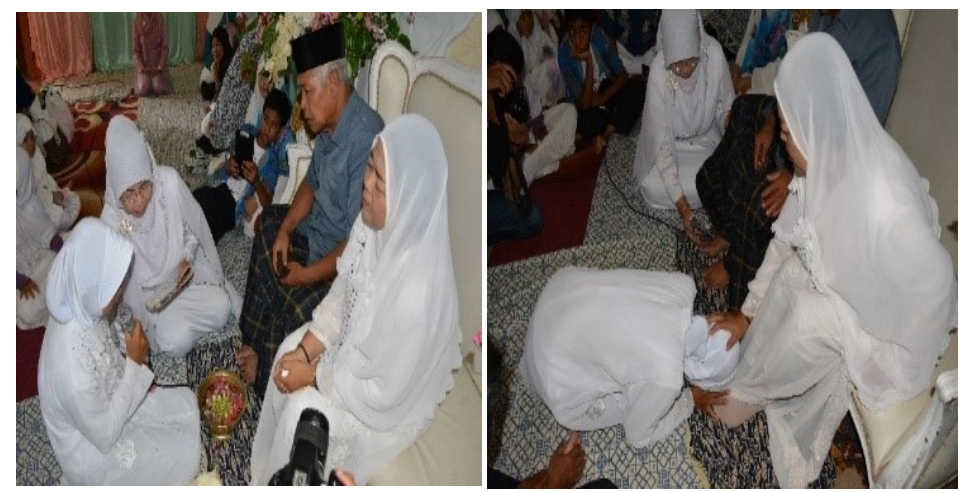

Gambar 3. Ngaras dan Sungkeman

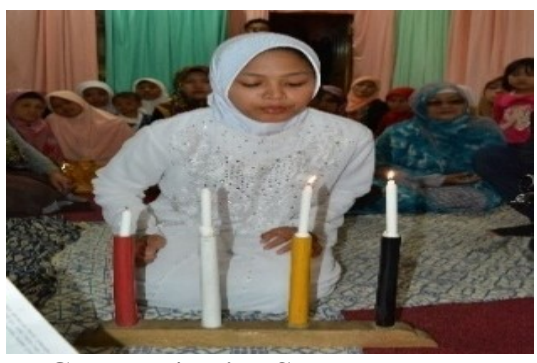

Gambar 4. Niup Seuneu

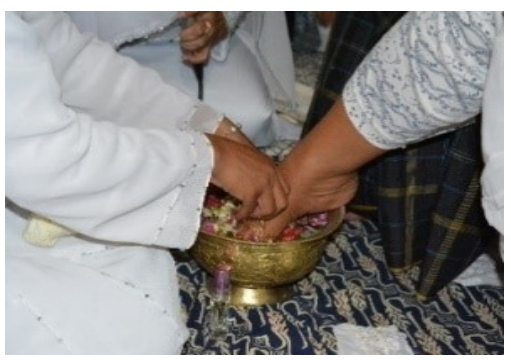

Gambar 5. Ngumbah Dampal Sampean 


\section{Situasi Komunikasi Tradisi Siraman pada Prosesi Pernikahan Adat Sunda}

Penggambaran situasi dari mulai pengajian, ngecagkeun aisan, ngaras, sungkeman, dan siraman.

Bagi Endah sebagai informan pertama dan pelaku siraman, berikut paparannya:

"Menurut teteh mah tergantung yang ini nya kan aya nu ngangge aya nu henteu orang teh jadi kembali deui kanu tradisi jadi kan orang sunda teh aya nu ngangge aya nu henteu benten-benten da sifat na teu wajib oge. Jadi menurut teteh mah simbolis karena kalo ritual mah panginten diharuskan. Yang sakral itu sungkeman. Kenapa? keluar we semuanya yang ingin disampaikan ke orangtua jadi apa ya sedih yang utama yang dirasakan". Itu dari siraman pas ngibakanna karena didukung juga dengan alunan musik sunda. Sungkeman karena ijin dan rido orang tua ada disana tapi kalo melingkupinya mah semuanya tapi yang lebih utama itu dari sungkeman karena ada doa restu dari orang tua tadi. Ya pasti merasakan. Cenderung ke khidmat nu diraoskeun panginten nya sedih aya, campur aduk sedihna mah jadi ada makna na kumpul keluarga, melepas ada ya melepas kesendirian jadi ketika pengajian juga sudah merasakan bahwa teteh akan lepas dari orang tua. Yang dirasain meminta izin buat menikah perasaanna sedih aya tapi da udah lumrah sebagai perempuan mah iya. Terus kata-kata yang terucap buat orang tua ketika meminta izin keluar sendiri secara spontanitas asli dari hati teteh. Iya pasti sangat sedih ya karena meminta maaf ka sepuh ka abah sareng mamah, yang dirasain orang tua yang dari kecil menggendong sekarang sudah dewasa giliran harus melepas sedih aya karena orang tua harus melepas tanggung jawabnya.". (Hasil wawancara dengan Ibu Endah Nurfitriana pada hari Jumat, 21 Juli 2017 pukul 10.00 di Cipanas Tarogong, Garut).

\section{Peristiwa Komunikasi Tradisi Siraman pada Prosesi Pernikahan Adat Sunda}

Peristiwa apa saja yang terjadi setelah dilakukannya tradisi siraman dalam kehidupan sehari. Bagi Endah selaku informan pertama dan pelaku siraman. Berikut paparannya:

"Harus siap memulai rumah tangga yang belum sama sekali kayak gimana ke depannya dengan doa orang tua, kakak ya alhamdulillah sekarang bisa ambil hikmahnya. Kebetulan keinginan sendiri ditambah anak terakhir ditambah keluarga semuanya mendukung. Kayak bunda sodara mamah memahami dan merasakan melepaskan anak tersebut tersebut teh teu semata-mata melepaskan jadi meskipun sudah menikah juga tetap kanyaah nu jadi indung kanyaah nu jadi sodara mah bakal terus aya ngalir jadi ada hikmahnya juga siraman tersebut teh mengikatkan silaturahmi jadi terus langgeng dengan kerabat yang lain." (Hasil wawancara dengan Ibu Endah Nurfitriana pada hari Jumat, 21 Juli 2017 pukul 10.00 di Cipanas Tarogong, Garut).
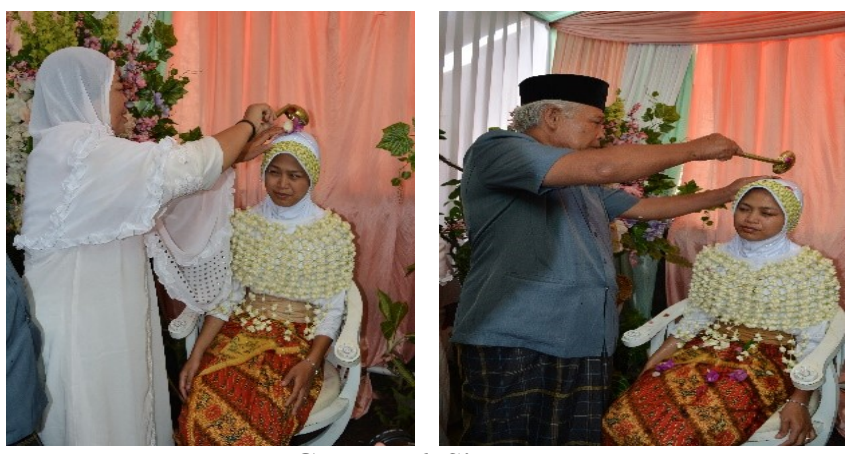

Gambar 6. Siraman

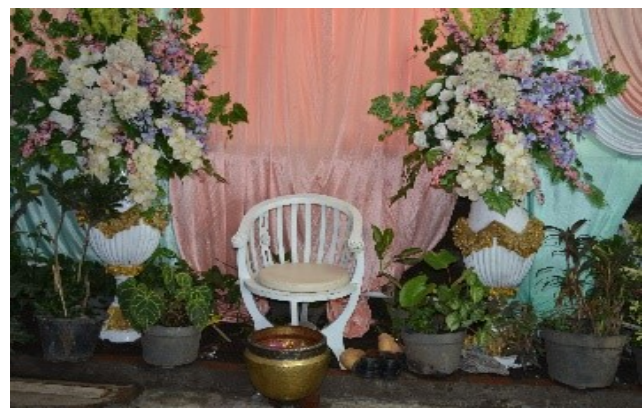

Gambar 7. Dekorasi Tempat Siraman 
Di sini Endah mengatakan setelah siraman dilaksanakan, harus siap memulai kehidupan berumah tangga. Siraman dilakukan atas keinginan sendiri dan dukungan dari keluarga. Partisipan memahami makna siraman dengan menceritakan kembali kepada informan atau pelaku siraman sebagian yang mereka lihat dan yang mereka pahami. Siraman mencapai tujuan dari informan yaitu meminta maaf kepada orang tua di waktu yang tepat.

\section{Tindakan Komunikasi Tradisi Siraman pada Prosesi Pernikahan Adat Sunda}

Tindakan komunikasi seperti apa yang dilakukan setelah selesainya seluruh prosesi siraman berupa tanggapan dari pernyataan di dalam siraman terdapat manfaat bagi kehidupan, di dalamnya terdapat nasihat untuk berperilaku baik. Menurut informan pertama, Endah Nurfitriana memaparkan pendapatnya setuju dengan pernyataan tersebut karena siraman bisa dijadikan pedoman untuk kehidupan. Selanjutnya paparan dari informan kedua, Aprilia sebagai pelaku siraman mengatakan setuju jika siraman dijadikan pedoman bagi kehidupan, karena di dalamnya mengandung arti masingmasing mulai dari pengajian, ngecagkeun aisan, ngaras, sungkeman, dan siraman. Kemudian informan ketiga, Seny sebagai pelaku siraman mengatakan setuju jika siraman dijadikan pedoman bagi kehidupan tetapi tidak menutup kemungkinan orang yang melakukan siraman menjalankan kehidupannya dengan baik.

\section{Makna Komunikasi Tradisi Siraman pada Prosesi Pernikahan Adat Sunda}

Makna pengajian menurut Aprilia dalam pengajian intinya mendapatkan doa dari semua orang yang hadir.

Sedangkan menurut Seny sebagai informan ketiga juga memaknai pengajian sebagai bentuk pengharapan kepada Allah SWT berupa doa-doa kebaikan, keselamatan, kelancaran, dan doa dijadikannya keluarga yang bahagia dalam berumah tangga.

Kemudian menurut informan Utju, sebagai pelaku siraman, makna siraman adalah menjadi pribadi yang disucikan kembali dengan diiringi ridho orang tua dan mendapat restu dari orang tua serta keluarga.

\section{Makna Komunikasi Verbal Tradisi Siraman pada Prosesi Pernikahan Adat Sunda}

Makna komunikasi verbal dalam tradisi siraman pada prosesi pernikahan adat Sunda terdapat dalam lagu-lagu yang dibawakan oleh juru kawih sebagai pelengkap dan pengantar siraman yang menambahkan kesan adat Sunda karena diiringi oleh alunan musik kecapi suling dan menambah kesan sedih, mengharukan sekaligus menggembirakan. Lagu-lagu yang dibawakan disesuaikan dengan tahapan prosesi yang sedang dijalankan pada saat itu.

\section{Makna Komunikasi Nonverbal Tradisi Siraman pada Prosesi Pernikahan Adat Sunda}

Makna komunikasi nonverbal dalam tradisi siraman pada prosesi pernikahan adat Sunda terdapat dalam alat dan bahan yang digunakannya. Tabel 4 adalah alat dan bahan yang digunakan dalam tradisi siraman dan makna dari alat dan bahan tersebut.

\section{Pembahasan Penelitian}

Berdasarkan data yang diperoleh peneliti, memiliki beberapa pandangan mengenai tradisi siraman dalam prosesi pernikahan adat Sunda, baik dari informan juga narasumber, karena peneliti melakukan penelitian di lapangan untuk mengetahui bagaimana makna dalam tradisi siraman pada prosesi pernikahan adat Sunda di Kabupaten Garut. Tradisi siraman pada prosesi pernikahan adat Sunda ini, dilihat dari aspek komunikasi erat kaitannya dengan budaya. Sedangkan dilihat dari aspek komunikasi siraman termasuk ke dalam komunikasi ritual, karena di dalam siraman ini ada ritual-ritual kecil yang dilakukan oleh calon pengantin pada saat prosesi berlangsung dalam rangkaian upacara pernikahan adat Sunda. Ritual-ritual kecil tersebut terdapat pada gerakan-gerakan yang dilakukan oleh calon pengantin secara berurutan yang mempunyai makna, serta terdapat pula pada alat-alat dan bahan-bahan yang digunakan sebagai perlengkapan siraman. 
Nilai kebaruan yang ada dalam tradisi siraman pada prosesi pernikahan adat Sunda, peneliti menggambarkan bahwa adanya keindahan sebagai rasa nikmat yang dianggap kualitas barang tertentu atau objek yang diinterpretasikan mengandung nilai keindahan, sebagai bentuk budaya dan adat istiadat.

\section{Tabel 4}

Makna Komunikasi Nonverbal

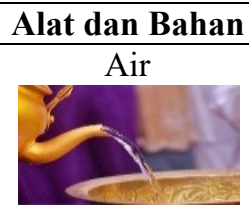

Bunga setaman tujuh macam (bunga melati, melati gambir, bunga mawar putih, bunga mawar merah, bunga kantil, bunga kenanga, bunga sedap malam)
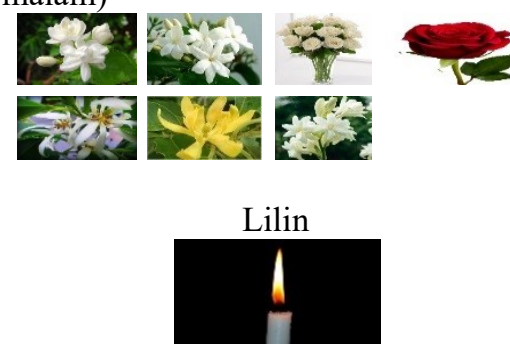

Bokor

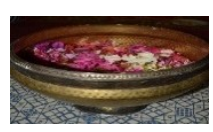

Parfum

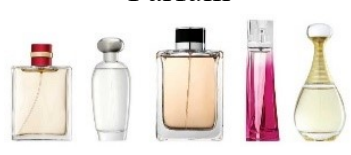

Kain batik (kain samping) tujuh buah

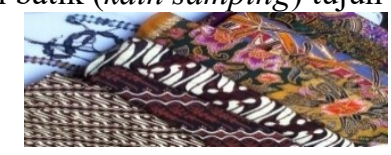

Gayung

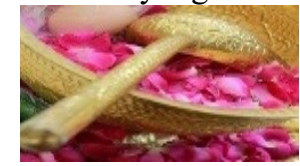

Baju putih/Kebaya

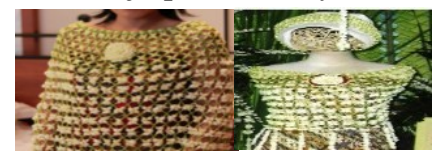

Emas
Bunga melati artinya dalam melakukan tindakan selalu melibatkan hati, tidak semerta-merta melakukan. Bunga melati gambir melambangkan kesederhanaan. Bunga mawar putih artinya ketentraman, sejahtera, dan damai. Bunga mawar merah artinya mempunyai makna kelahiran diri manusia ke dunia, bunga kantil artinya memiliki jiwa spiritual yang kuat untuk meraih sukses lahir maupun batin, bunga kenanga artinya generasi penerus leluhur, dan bunga sedap malam artinya keharmonisan dan ketentraman.

Simbol penerangan, yang artinya untuk menerangi dalam kehidupan berumah tangga.

Lambang kemuliaan ditiru dari warnanya yang emas.

Wewangian yang merupakan simbol sebagai perumpamaan wanginya surga dan mempunyai makna menjaga kehormatan orang tua dan keluarga jangan sampai dikotori tetapi harus wangi atau baik di mata masyarakat.

Melambangkan bahwa waktu itu ada tujuh hari kita menjalankan kehidupan dari mulai Senin-Minggu.

Diartikan mampu mengayomi keluarga

Kebaya adalah baju perempuan bagian atas, berlengan panjang, dipakai dengan kain panjang melambangkan kepatuhan, kehalusan, dan tindak tanduk wanita yang harus serba lembut. Dilambangkan bersih hatinya, ikhlas dan suci.

Lambang kemuliaan 


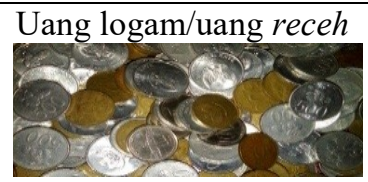

Alat penukar/ alat standar mengukur nilai yang sah, yang dikeluarkan oleh pemerintah. Uang logam sebagai kemakmuran lambang budaya dan harta dunia.

Sumber: Hasil Penelitian 2017

Salah satu bentuk dari adat istiadat adalah siraman adat perkawinan Sunda yang selama ini mengandung nilai estetik yang sangat menarik dan mengagumkan. Prosesi perkawinan adat Sunda secara garis besar di dalamnya terdapat ritual yang sangat sistematis dan tertib, ritual tersebut di antaranya adalah acara ngalamar (melamar), seserahan (menyerahkan barang atau alat-alat perlengkapaan untuk resepsi, dari keluarga mempelai pria), prosesi akad nikah, upacara panggih (bertemu muka), upacara sawer dan buka pintu yang di dalamnya terdapat syairsyair yang sangat indah dan merdu. Selain itu, tata busana pengantin khas Sunda semakin menambah keindahan dan keunikan dari prosesi perkawinan adat Sunda. Secara keseluruhan dari ritual perkawinan adat Sunda di dalamnya mengandung unsur-unsur estetika yang meliputi unsur kesatuan, ketertiban, keseimbangan, dan sistematis. Unsur-unsur tersebut berpadu dan membentuk nilai estetika yang sangat menarik bagi setiap orang yang melihatnya.

Berdasarkan hasil temuan dalam memahami komponen komunikasi pada tradisi siraman dalam prosesi pernikahan adat Sunda, maka terdapat ciri-ciri umum perilaku komunikasi pada tradisi siraman dalam prosesi pernikahan adat Sunda, yaitu: (1) Berkomunikasi dengan cara unik, tidak secara langsung tetapi diwakili oleh orang-orang tertentu yang disebut juru tembang atau juru mamaos (pengatur acara yang biasanya sebagai penyanyi lagu-lagu adat Sunda); (2) Selalu dalam bentuk adat Sunda dan doa-doa; (3) Selalu dilaksanakan di kediaman calon pengantin atau disebut rumah orang tuanya; (4) Komunikasi pada tradisi siraman menggunakan bahasa Sunda puitis dan bahasa Sunda halus; (5) Menggunakan kalimat yang dibuat secara teratur namun dapat dipahami; (6) Dipengaruhi oleh sistem budaya yang dianut.

Aspek komunikasi pada tradisi siraman dalam prosesi pernikahan adat Sunda senantiasa dilakukan dalam bentuk pengucapan doa-doa dan adat yang dilakukan oleh pengatur acara (juru tembang, juru kawih/mamaos). Komunikasi pada tradisi siraman menggunakan bahasa Sunda puitis dan bahasa Sunda halus dan karenanya semua yang hadir dalam setiap acara harus menginterpretasikan maksud dari doa yang diucapakan oleh ustaz/ustazah dan pengatur acara (juru tembang/mamaos). Namun demikian, secara umum doa-doa yang diucapkan senantiasa dapat dipahami oleh partisipan yang hadir. Komunikasi dalam tradisi siraman sangat dipengaruhi oleh sistem budaya yang dianut, pada setiap rangkaian acaranya disyaratkan terlebih dahulu mempersiapkan hal-hal yang harus ada dalam setiap rangkaian acaranya seperti mempersiapkan macam-macam bunga tujuh rupa, gentong atau tempat air yang terbuat dari kuningan, kain batik sebanyak tujuh buah, lilin, handuk kecil, wewangian, kendi dari tanah liat, gayung dari kuningan. Syaratsyarat tersebut tidak hanya sekedar ciri semata melainkan memiliki fungsi dan makna yakni untuk kebaikan-kebaikan dalam kehidupan.

Selain dari hasil wawancara dengan informan, peneliti melakukan proses triangulasi dengan melakukan wawancara pada Agus Mulyadi, merupakan seniman sekaligus budayawan Sunda di Kabupaten Garut. Narasumber bergabung dalam beberapa lingkung seni seperti lingkung seni Gilang Kusumah Bandung, Lingkung seni Kujang Kencana Garut, lingkung seni Gentra Pancaniti Garut, dan ketua lingkung seni PUJASMANIK Garut dari tahun 2000 sampai sekarang. Menurut Agus Mulyadi siraman artinya menyucikan diri, meminta doa restu dari orang tua, kerabat, dan saudara atau dapat dikatakan meminta doa restu dari orang-orang yang dituakan oleh calon pengantin dalam keluarga. Tujuan dari siraman adalah meminta izin dan doa restu calon pengantin yang akan menikah kepada 
orang tua dan kerabat yang hadir pada saat itu, dengan harapan dalam proses pernikahan diberikan kelancaran dan dalam menjalankan kehidupan berumahtangga disertai kebahagiaan.

Tradisi siraman pada prosesi pernikahan adat Sunda ini relevan dengan teori etnografi komunikasi yang bersifat spesifik menjelaskan dan memahami perilaku komunikasi dalam kebudayaan tertentu sehingga sifat penjelasannya terbatas pada suatu konteks tempat dan waktu tertentu. Etnografi komunikasi juga bersifat global karena mencoba memformulasikan konsepkonsep dan teori untuk kebutuhan pengembangan metateori global komunikasi antarmanusia (Kuswarno, 2008). Hal ini juga diperkuat oleh hasil penelitian dari (Pertiwi, 2014), tentang Aktivitas Komunikasi dalam Tradisi nyawer pada Proses Pernikahan Adat Sunda di Kota Bandung yang menggambarkan tentang bagaimana komunikasi dalam tradisi nyawer pada proses pernikahan tradisional Sunda. Penelitian Pertiwi ini membahas kegiatan komunikasi dilihat dari situasi komunikatif, peristiwa, dan tindakan komunikatif. Subjek penelitian adalah beberapa orang yang berpartisipasi pada saat upacara pernikahan berlangsung. Hasil penelitian menunjukkan bahwa situasi komunikatif yang melibatkan keluarga dari kedua mempelai, juru sawer, dan makeup serta tamu undangan saat upacara nyawer berlangsung di luar gedung. Peristiwa komunikatif upacara nyawer adalah tradisi dalam bentuk perayaan ritual khusus yang berlangsung selama 30 menit dan dilakukan setelah upacara selesai, sedangkan tindakan komunikasi nyawer dalam tradisi adat pernikahan Sunda yang berbentuk pernyataan dalam bentuk perilaku nonverbal muncul dari bentuk beras, kunyit, koin, bunga, permen, sirih. Hasil penelitian ini bahwa kegiatan komunikasi dalam tradisi nyawer pada proses pernikahan tradisional Sunda dimulai dari kebiasaan nenek moyang mereka yang dalam pelaksanaannya memiliki karakteristik serta makna keharmonisan keluarga.

Gambaran rangkaian acara dalam sebuah pernikahan memang berbeda-beda di setiap daerahnya, dengan demikian setiap daerah memiliki ciri khas masing-masing kebudayaannya, bahkan ada yang melaksanakan dan tidak sama sekali. Pernyataan tersebut, sependapat dengan Hashim (1998) yang menyatakan bahwa "Masyarakat sesungguhnya yang masih memegang erat tradisi kebudayaan Sunda secara kental dalam kehidupan sehari-hari, selalu memegang teguh dan menjaga keutuhan kebudayaannya sendiri, akan tetapi kebudayaan yang tidak digunakan atau diwariskan bukan berarti memiliki kecenderungan jauh dari budaya". Hal ini, juga diperkuat oleh Warnaen dalam Ekadjati (2009), yang menyatakan bahwa "Dalam melihat masyarakat Islam di Asia Tenggara seseorang tidak bisa memisahkan hubungan antara adat dan Islam. Pandangan yang melakukan pemisahan telah membuat sebuah penyederhanaan dan terkadang membingungkan". Jadi, peneliti simpulkan bahwa kebudayaan Sunda dalam upacara pernikahan yang melaksanakan tradisi siraman pada prosesi adat Sunda di dalamnya memiliki makna dan pesan yang terkandung, sehingga perbedaan dari setiap sudut pandang harus diminimalisasi dalam rangka memberikan pemahaman yang lebih baik dan masukan yang positif dalam pelestarian warisan budaya nasional, khususnya dalam tradisi siraman pada prosesi pernikahan budaya adat Sunda. Berdasarkan hasil wawancara juga didapat dari informan peneliti menemukan kesamaan pemahaman tentang siraman yaitu untuk menyucikan diri secara lahir dan batin dan kesamaan tujuan yaitu untuk meminta izin dan doa restu dari kedua orang tua, kerabat, dan orang yang dituakan dalam keluarga atau biasa disebut sesepuh keluarga.

\section{PENUTUP}

\section{Simpulan}

Komponen komunikasi yang terdapat dalam tradisi siraman pada prosesi pernikahan adat Sunda berkomunikasi dengan cara unik, tidak secara langsung tetapi diwakili oleh orang-orang tertentu yang disebut juru tembang atau juru mamaos. 
Topik atau fokus referensi yang menjadi pokok makna dari simbol-simbol yang dipertukarkan selalu dalam bentuk doa. Komunikasi pada tradisi siraman menggunakan bahasa Sunda puitis dan bahasa Sunda halus, menggunakan kalimat yang dibuat secara teratur namun dapat dipahami, dipengaruhi oleh sistem budaya yang dianut. Situasi komunikasi dalam tradisi siraman pada prosesi pernikahan adat Sunda dalam keseluruhan rangkaian acara, mulai dari pengajian, ngecagkeun aisan, ngarassungkeman, dan siraman, situasi komunikasi yang tergambarkan dari keseluruhan rangkaian aktivitas acara tersebut adalah suasana sakral, keakraban, kegembiraan, kondusif, dan kental suasana adat tradisional Sunda. Situasi tersebut didukung oleh alunan musik kecapi suling sebagai ciri khas musik Sunda dan dekorasi khas Sunda. Peristiwa komunikasi yang tergambarkan dalam tradisi siraman pada prosesi pernikahan adat Sunda mulai dari awal hingga akhir. Tindak komunikasi dalam tradisi siraman pada prosesi pernikahan adat Sunda terdiri dari bentuk komunikasi verbal dan nonverbal. Segala bentuk komunikasi verbal dan nonverbal tersebut dilakukan baik secara lisan maupun secara simbolik. Bentuk komunikasi verbal dapat berupa perintah, pernyataan, ataupun permohonan. Komunikasi verbal yang terjadi selalu didukung oleh berbagai macam komunikasi nonverbal oleh pelakunya. Simbol-simbol tersebut memiliki makna tersendiri yang dipahami secara bersama, simbol-simbol dalam tradisi siraman meliputi air, bunga, lilin, kain batik, pakaian, wewangian, bokor, dan gayung. Makna komunikasi dalam tradisi siraman dibagi dalam dua bentuk komunikasi verbal dan komunikasi nonverbal. Makna komunikasi verbal dalam tradisi siraman terdapat dalam lagu-lagu yang dibawakan oleh juru kawih yang memiliki arti penggambaran kasih sayang orang tua terhadap anaknya dan pengambaran kasih sayang anak terhadap orangtua, berupa nasihat, doa-doa dan wejangan untuk kehidupan lebih baik. Sedangkan makna komunikasi nonverbal dalam tradisi siraman terdapat dalam peralatan yang dipakai sebagai simbol-simbol pertukaran pesan.

\section{Saran}

Penelitian ini diharapkan dapat dijadikan sebagai literatur atau sumber tambahan dalam memperoleh informasi yang berkenaan dengan aspek budaya, sehingga dapat mengeksplorasi khususnya dalam pendekatan kualitatif. Hasil penelitian ini dapat memberikan konstribusi bagi pelaku budaya dan pemerhati budaya jangan sekalikali mengabaikan tradisi atau kebudayaan Sunda serta ikut mendukung tradisi asing yang masuk, karena budaya Sunda sebagai ciri kebudayaan yang unik, sehingga terus dapat dilestarikan.

\section{DAFTAR PUSTAKA}

Bahari, H. (2011) Kitab Budaya Nusantara. Jogjakarta, Diva Press.

Budiman, E. (2008) Upacara Adat Nusantara. Bandung, CV. Gaza Publishing.

Dewi, I.G.A.C. (2015) Aktivitas Komunikasi Upacara Pernikahan Suku Sasak. [Online]. Universitas Telkom. Available from: http://repository.telkomuniversity.ac.id/pust aka/102263/aktivitas-komunikasi-upacarapernikahan-suku-sasak-studi-etnografikomunikasi-dalam-upacara-kawin-culik-didesa-rembitan-lombok-tengah-.html.

Ekadjati, E.S. (2009) Kebudayaan Sunda: Suatu Pendekatan Sejarah. Jakarta, Dunia Pustaka Jaya bekerja sama dengan Pusat Studi Sunda.

Eliade, M. (2002) Mitos Gerakan Kembali yang Abadi (Terj. Cuk Ananta). Yogyakarta, Ikon Teralitera.

Fatmawati, E. (2016) Makna Pesan Tari Merak Dalam Upacara Pernikahan Adat Sunda. Universitas Garut.

Fiske, J. (2004) Cultural and Communication Studies. Yogyakarta, Jalasutra.

Garna, Y.K. (2009) Metoda Penelitian Kualitatif. Bandung, Judistira Foundation dan Primaco Akademika Bandung.

Hashim, M.E. (1998) Rupa-Rupa Upacara Adat Sunda Jaman Ayeuna. Bandung, Pustaka.

Hymes, D. (1974) Foundations in Sociolinguistics: An Ethnographic Approach. Philadhelpia, University of Pennsylvania.

Ibrahim, A.S. (1992) Panduan Penelitian Etnografi Komunikasi. Surabaya, Usaha Nasional.

Kuswarno, E. (2008) Etnografi Komunikasi: 
Suatu Pengantar dan Contoh Penelitiannya. Bandung, Widya Padjajaran.

Lerina, W. (2015) Garapan Penyajian Upacara Siraman Calon Pengantin Adat Sunda Grup Swari Laksmi. Universitas Pendidikan Indonesia.

Mustapa, H. (2010) Adat Istiadat Sunda (Terj. M. Maryati Satrawijaya). Bandung, PT. Alumni.

Nurhadi, Z.F. (2015) Teori-Teori Komunikasi: Teori Komunikasi dalam Perspektif Penelitian Kualitatif. Bogor, Ghalia Indonesia.

Pertiwi, R.A. (2014) Aktivitas Komunikasi Dalam Tradisi Nyawer Pada Proses Pernikahan Adat Sunda di Kota Bandung (Studi
Etnografi Komunikasi Mengenai Aktivitas Komunikasi Dalam Tradisi Nyawer Pada Proses Pernikahan Adat Sunda di Kota Bandung). Universitas Komputer Indonesia.

Rezeki, F. (2015) Mengenal Budaya Sunda Lebih Dekat. Bandung, PT. Sarana Tutorial Nurani Sejahtera.

Rosidi, A., Ekadjati, E.S. \& Chaedar, A. (2006) Konferensi Internasional Budaya Sunda. Bandung, Yayasan Kebudayaan Rancage \& PT. Kiblat Buku Utama.

Saripudin, A. (2010) Makna Kearipan Lokal Dalam Mempertahankan Jati Diri Bangsa (Dilihat dari Sudut Pandang Budaya Sunda). Ciamis, PT. Galuh Pratama. 